\title{
The geography of the nationalist right in Portugal: outlines of an emerging process
}

\author{
A geografia da direita nacionalista em Portugal: \\ contornos de um processo emergente
}

\author{
Paulo Miguel Fernandes Madeira [I] \\ Katielle Susane do Nascimento Silva [II] \\ Jorge Silva Macaísta Malheiros [III]
}

\begin{abstract}
The emergence of the nationalist right in Portugal in the legislative elections of 2019 is contextualized here in the framework of similar populist phenomena that have emerged in Europe in recent decades and in the geography of discontent associated with them. An analysis of the territorialization of the votes for this new party, named "Chega" (Enough), at the municipal level presents a pattern that does not match what electoral geography has been in Portugal since the 1974 democratic revolution. The correlations with a wide range of variables point to base voters associated with some elements of social and economic disadvantage and strongly motivated by identity issues. At the same time, the sociology of Chega voters presents some surprising aspects when compared to what is known about most European cases.
\end{abstract}

Keywords: electoral geography; geography of discontent; Portugal; nationalist right; European populism.

\section{Resumo}

A emergência da direita nacionalista em Portugal nas eleições legislativas de 2019 é aqui contextualizada nos fenómenos populistas europeus do mesmo tipo nas décadas mais recentes e na geografia do descontentamento que lhes está associada. A análise da territorialização da votação nesse novo partido, o Chega, na escala municipal, apresenta um padrão que não se coaduna com o que tem sido a geografia eleitoral em Portugal desde a Revolução Democrática de 1974, sugerindo as correlações com um conjunto alargado de variáveis com uma forte motivação identitária da sua base eleitoral, que aparece associada a alguns elementos de desvantagem social e económica. Simultaneamente, a sociologia dos eleitores do Chega apresenta alguns aspetos surpreendentes em face do que se sabe para a generalidade dos casos europeus.

Palavras-chave: geografia eleitoral; geografia do descontentamento; Portugal; direita nacionalista; populismo europeu. 


\section{Introduction}

At the beginning of the $21^{\text {st }}$ century in Europe, it became increasingly evident that the challenge to the current political-economic regime was no longer a minor phenomenon limited to the fringes or small parties of the political-electoral system and that this challenge has become increasingly important. Such process was based on left and right-wing parties and resulted from resentments that are not always easy to identify.

The challenge of the left has traditionally been directed at socioeconomic injustices related to capitalism in general and in recent decades to neoliberalism in particular. In addition, there is an increasing concern with forms of subordination based on different identity elements (e.g., gender, ethnicity, sexual orientation). Despite progresses towards a greater equality of principles and alter-globalization proposals, this leftwing challenge has not been able to call into question the architecture of the international political economy system on which globalism rests and on which predatory formations are articulated (Sassen, 2014, p. 13), formations that ensure the concentration of wealth to the top of the income pyramid and allow the global system to function.

As far as the right is concerned, there is a discourse that challenges that architecture, or at least part of it, especially if it is a right with more nationalist, sometimes fascist-inclined characteristics. Therefore, this challenge rests on issues related to national sovereignty, culture and identity, normally considered in a static and monolithic way, although it is also associated with socioeconomic aspects. In this sphere, it emphasizes the negative consequences of globalization on the employment and the income of vast sectors of the populations of many European countries, sometimes with a typically left-wing economic agenda (Gordon, 2018, p. 95).

It was this right, above all, that recently has had the most success with voters, particularly the losers of globalization, and managed to grow consistently in the most advanced European countries and in many peripheral ones, of which Portugal is an example.

The parties of the new nationalist and anti-systemic right have been able to obtain support mainly among older, white, working-class voters with a low income and low qualification, who, therefore, find it more difficult to prosper in the current European economy, according to several studies on this phenomenon (Dijkstra, Poelman and Rodríguez-Pose, 2019; McCann, 2019; Gordon, 2018; Guilluy, 2014). The voters with these characteristics are common people, grassroots citizens, who are among those who have lost the most with the evolution of the European economy in the last decades; this loss has been characterized by an increasing deindustrialization in many regions and countries and by the increasing importance of the services sector. In Portugal, the antisystem and/or populist vote with a significant dimension and parliamentary representation was the left-wing vote until recently, as we will discuss in detail below. However, in the 2019 legislative elections, a right-wing party with a speech and a political proposal that can be framed within the nationalist and populist 
right, the Chega party, presented itself for the first time to voters and managed to elect a deputy to the Assembly of the Republic (AR): André Ventura, its founder. In its political manifesto, Chega is depicted as "a national, conservative, liberal, and personalist party" (Chega, s/d).

In the context of the recent reconfiguration of the European politicalelectoral framework, in which parties with these conditions have gained relevance and in some cases put the hegemony of traditional forces at risk, the election of a deputy of a party with these characteristics in Portugal ${ }^{1}$ soon after it appeared for the first time in elections to the AR is of particular significance. Therefore, it is important to understand the reasons behind this first electoral success. Subsequently, in the legislative elections of the Autonomous Region of the Azores in 2020, this party was the fourth most voted, obtaining just over five percent of the votes, and managed to elect two regional deputies. ${ }^{2}$

This result allowed Chega to negotiate parliamentary support for a coalition government led by the second most voted party (the center-right Social Democratic Party), thus removing the Socialist Party (center-left) from the Regional Government. This party was the most voted but did not obtain the absolute majority in Parliament. More recently, the Chega party leader, André Ventura, ran for the presidential election on January 24, 2020, and came in third place (out of seven candidates), obtaining around half a million votes $(11.9 \%)$, which has confirmed the ongoing growth process around its party.
Several polls carried out in 2020 and in the beginning of 2021 have reported more than $5 \%$ of vote intentions for Chega in new legislative elections, sometimes approaching $10 \%$ of votes. This result would place Chega as one of the three or four major Portuguese parties. With this in mind, this study aims to contribute to the understanding of the geography of this phenomenon in Portugal and to discuss the factors that underlie the detected patterns.

In this context, the objective we propose here is to analyze the electoral results of the Chega party in the 2019 legislative elections from a geographical perspective. Therewith, we aim to (1) understand the political-electoral origins of its voters, (2) analyze its main socioeconomic characteristics considering short-term territorial transformation dynamics, and (3) identify possible similarities and differences with voters who have supported parties and movements of this type in other European countries.

To reach these objectives, we analyzed variables of an electoral, social, and economic nature using linear correlation and multiple linear regression. The data were obtained from the National Statistics Institute (INE), the High Commission for Migration (ACM), the Ministry of Internal Affairs (MAI), and the Immigration and Borders Service (SEF). The period we chose for analysis was 2015 to 2019, the years of the last two legislative elections in Portugal. However, some structural social and economic variables are from 2011, the year of the last census in Portugal. These temporal differences posed challenges to this study; however, they did not make the analysis unfeasible. 


\section{The rise of the nationalist right, populism, and "places that do not matter" in Europe}

\section{The advance of anti-system \\ movements in Europe}

The first major milestone of the challenge to the political and economic regime in force in Europe happened in 2005, when two electoral defeats of the central parties of the system occurred. In that year, the European Constitutional Treaty, which called for a Constitution for the European Union, was refused in a referendum in France $154.67 \%$ of nay votes) and in the Netherlands (61.54\% of nay votes). Indeed, the challenge to the system was older, by both the left and the right; although extreme right parties, compared to extreme left parties, have historically obtained less votes. The first electoral success of the current anti-system right was perhaps that of the French National Front, founded in 1972 (renamed "Rassemblement National" in 2018). It managed to elect its leader, Jean-Marie Le Pen, as a Member of the European Parliament in 1984. However, this challenge never reached the point of changing the positions of EU leaders, in opposition to what happened following the 2005 referendums.

After rejecting the Constitutional Treaty, other electoral acts marked the rise of parties in several countries that challenged the integration to the EU, aspects of the socioeconomic system, and often the "shrinking" of national sovereignty and a supposed loss of identity. These parties have associated immigration to Europe and the presence (even if consolidated) of immigrant communities and their descendants with several of these processes. The maintenance of the Fidesz party in power in Hungary since 2010, with Viktor Orbán as prime minister, is an example of the success of this nationalist identitarian right, authoritarian to a certain degree, mixed with some skepticism towards the EU. In Poland, this phenomenon has been led by the Law and Justice party (PiS).

The year 2016 was an important turning point due to the victory of "no" in the referendum on the United Kingdom's permanence in the European Union and the election of Donald Trump as President of the United States, a phenomenon that clearly fits in with what we describe here. The latter, because of the worldwide influence of the United States, has given new momentum to such movements in Europe. In the 2016 Austrian presidential elections and in the 2017 French elections, candidates from the nationalist right came in second; in Germany, also in 2017, the rise of the AfD (Alternative für Deutschland) in the legislative elections made it difficult to organize a majority in support of a new government.

\section{Populism and its recent success in the right}

Anchored mainly on the right, this phenomenon has been called "populism," by which new political parties adopt an insurgent discourse against hegemonic forces in the sociopolitical system. It focuses on the concerns of most of the European popular classes and often adopts a simplistic and superficial language in their messages. In fact, the concept of populism is not clear. It is subject of controversy in political science (Lisi, Llamazares and Tsakatika, 2019; Dijkstra, 
Poelman and Rodríguez-Pose 2019, pp. 3-4; Gordon, 2018, p. 97; Mudde, 2004, p. 541). The definition that seems most accepted is the one that regards populist parties as establishing a dichotomy between the people and an allegedly selfish elite that is distant from the rest of the population. That elite is sometimes corrupt, thus creating a dichotomy between an "us," the people, and a "them," the leaders, regarded as enemies of ordinary people (Bonikowski, 2017; Mudde, 2004). Another possible definition is that which regards populism as the rejection of the moral and intellectual authority of the ruling class, replacing it for common-sense responses of popular classes (Gordon, 2018, pp. 97).

Populism can be considered an ideology, as Mudde (2004) posits, but this too is controversial. It can also be considered a form of political mobilization or a discursive framework (Bonikowski, 2017), or just a "political logic - a way of thinking about politics" (Judis, 2016, p. 14). The definition of populism as the transposition of the opposition between two poles - the people and an elite - to the party level was expanded by Judis (ibid.), who argued for a type of populism that also opposes the people to a third group that, in Western societies, may be immigrants and ethnic or religious minorities. This type of populism categorizes society into three groups and is therefore called "triadic." If left-wing populisms tend to defend the people against the elite in a vertical perspective and can thus be designated as "dyadic," right-wing populisms, namely the contemporary European nationalist right, in addition to this opposition, also tends to incorporate the opposition between the people and other groups considered to be outside the supposedly traditional and original national society and are even regarded as a threat to it.

The opposition between "people" and "elite," or between "people" and "ruling class," may invoke different groups and/or specific powers, such as ethnic or socioeconomic groups, Wall Street and international finance, or European technocratic elites (Freire, 2019a). Note that some of the oppositions are related to issues of the right; others evoke issues of the left. This allows understanding why Mudde and Kaltwasser (2017, pp. 5-6) classify populism as "a thin ideology" or "a low-density ideology" (expression preferred by the Portuguese political scientist André Freire).

The lack of ideological-programmatic density of populism implies that it does not provide complex and wide-scope solutions to important political issues from the outset; for this reason, populism is almost always associated with other ideological concepts and elements. Thus, populism may take very different programmatic forms. An example of this polymorphism is the idea, proposed by Mouffe (2018), of a populism that renews the left, against neoliberal hegemony, and compatible with liberal democracy. Here, populism is regarded as a way of doing politics, not as an ideology (Freire, 2019b).

For populist ideas to acquire a politicalelectoral relevance, there must be political movements that promote them and run for elections, and that a substantial part of the electorate must be willing to accept and vote for them. One of these elements may precede the other to a greater or lesser extent, and it is possible that they feed themselves back. Having some predisposition for this populism among the electorate may lead to the 
emergence of parties that support it, which, in turn, may expand their electoral base by amplifying these ideas in the public debate.

The populist parties that have emerged, or that from a given moment have grown rapidly, sometimes did so on the basis of politicians who are entrepreneurs (Gordon, 2018, p. 98) and expressly mobilized themselves to attract the vote of popular discontent that people felt existed in society and to which the traditional parties of the system did not respond. The reasons for this popular discontent have often been attributed to the ruling classes' disinterest in what happens to the people. Sometimes, there seems to be an entrepreneurial approach by which a group of politicians decide to embody popular discontent, as if it was a market opportunity.

\section{Reasons for voter adhesion}

Adherence to these ideas seems to be based on two orders of reasons that are reflected in a successful electoral discourse. On the one hand, growing economic difficulties, with loss of income and even of jobs, have been affecting a substantial part of the population (Dijkstra, Poelman and Rodríguez-Pose, 2019; Ferrão, 2019), without the prospect of reversing the situation in the current context. On the other hand, many people feel forsaken or even marginalized and threatened from a political, cultural, and even identitarian point of view, especially when economic difficulties coexist with strong migratory currents, be it the local population leaving in search of job opportunities or the entry of foreign population, which sometimes occurs simultaneously. This generates fear or even a feeling of loss of identity, which may be reinforced by the post-materialist agenda on the part of metropolitan populations.

This transformation has been closely linked to neoliberal globalization, which has led to a wide opening of European economies to international trade, investments, and capital circulation. This situation led to a large increase in the import of cheap agricultural and industrial goods, in the latter case mainly from Asia, and allowed an important part of European industrial groups to start producing in Asia goods they used to produce and sell in Europe, goods that sometimes they also exported. Obviously, this has drastically reduced industrial employment in Europe, mainly affecting less qualified and older working people, who in Europe are largely white and among those who have been designated as "losers of globalization" in Western developed countries.

If the internationalization of goods and capital markets has been more intense than that of labor markets, the latter is also essential to ensure the profit and competitiveness of economic sectors, relying on workforce segmentation (according to gender, ethnicity, geographic origin) and on the reduction of its costs. If the most qualified immigrants are essential to ensure creativity and innovation in sectors such as R\&D or telecommunications in developed countries in Europe, the least qualified immigrants ensure labor supply to sectors with limited geographical transferability and marked by seasonality or by strong susceptibility to cyclical crises (e.g., agriculture, civil construction and public works, hotels) (Malheiros, 2012). In this context, the 
recruitment of foreigners becomes frankly desirable and increases competition with national workers, thus helping to feed the antiimmigrant discourse that assigns to foreigners - and not to the conditions of the economic system and to employers - the responsibility for deteriorating the life conditions of the national workers.

However, voting in right-wing nationalist parties in Europe has also been linked to issues of behavior on the part of voters towards a set of values related to attitudes towards immigrants, multiculturalism, authority, and distrust of national and international governance, often without an explicit relationship with economic insecurity (Inglehart and Norris, 2016, apud Gordon, 2018 , p. 98). These people tend to consider their values and feelings of identity threatened by the sharing of their daily living spaces with culturally different immigrant communities, especially Islamic ones, mainly when the growth of the latter is recent and fast (Ferrão, 2019, pp. 62-63) and feelings of economic and social loss are heightened.

In some regions, this situation diluted the feeling of living in a homogeneous nationstate with its own, falsely static values and identities, generating a strong reaction on the part of certain segments of the population. The populist right not only takes advantage of these feelings, but indeed nourishes them, which is contrary to the social-liberal consensus and the acceptance of the cultural diversity principles, which have been hitherto dominant.

For Fukuyama (2019), the economic and nationalist dimensions have been combined by right-wing populism to reinforce nationalisms. Right-wing populism has managed to take advantage of the resentment of a working class that has lost jobs due to, for example, subcontracting and competition with foreign populations in globalized capitalism. In this way, resentment ends up displacing the effects of capitalism to the foreign population, disseminating discourses based on national identity and sometimes hate speech.

Thus, the populist vote (especially on the right) is also a cultural refusal of the postmaterialist agenda, but which has strong material consequences for Europeans in the most fragile social classes in terms of income and the sociocultural environment into which they have become territorially embedded. In fact, Gordon (2018, p. 109) found a relationship between recent immigration and populist support among workers of small establishments, and between long-term changes in the composition of the population and support for populist parties by long-term residents in affected regions. These people are "localists who see in the territory, in their territories, in the places where they live, the last anchor of social capital, of the sociability they have left and of the security to which they aspire" (Ferrão, 2019, p. 63).

The revolt of the "places that don't matter" and the geography of resentment

Several geographers have studied the phenomena of electoral insurgency in the context of the populist vote and in the context of the anti-European Union vote (which partly coincides with the populist one, but not entirely). They have come to the conclusion that this type of electorate is often more concentrated in some places than in others. This has given rise to a new geography, the 
geography of discontent or resentment the expression adopted in this issue of the Cadernos Metrópole. What these places have in common is that they are poor or declining areas and often have been neglected for a long time by political power, to the point it has made them feel as "places that don't matter" - the expression used by Rodríguez-Pose (2018) - from the point of view of economic and social development.

Neoliberal globalization has resulted, in Europe and other places, in the strengthening of some forces that act towards the divergence of socioeconomic development at the regional scale, mainly through international trade (Madeira, 2019). In general, there has been a strengthening of large metropolitan centers and a decline (relative or absolute) of the most peripheral regions.

In Western Europe, these problems affect mainly regions with small and mediumsized industrial cities, which have suffered a decline in employment or income, and also their surrounding suburbs and rural areas, where income has stagnated (Martin et al., 2018, p. 9). This is associated with a combination of declining income per capita compared to the national averages, job losses, and declining labor force.

Part of these regions had once been prosperous; the reality of a decline (absolute or relative) in the last few decades may have given their populations an increased sense of loss in relation to areas that have always ranked below the average regarding income and/or job loss. These places that don't matter, or "places that don't count" (Ferrão, 2019), have remained in this situation not only because of the dynamics induced by neoliberal globalization, but also because of the absence of regional development policies strong enough to counter them (Madeira, 2019).

Voters in these places began to revolt at the ballot boxes, and this phenomenon took on increasing dimensions, as mentioned above, to the point of calling into question the political and economic order that has prevailed in the last four decades. Rodríguez-Pose (2018) called it "the revenge of the places that don't matter" against the feeling of being left behind.

The causes of these electoral revolts are already generically identified in Europe. Detailed analysis were written for national cases, such as the French and the British ones, essentially confirming these trends. In France, the increase in inequality resulting from globalist neoliberalism has led to a social fracture between more localized popular classes and globalized elites, and the electoral options tend to be different (Guilluy, 2014). In the UK, such electoral uprisings have concentrated heavily on territories that have suffered prolonged declines (McCann apud Rodríguez-Pose, 2018). This was evident in the territorial patterns of votes for the UK to stay or to leave the European Union in the 2016 referendum.

\section{Methodology}

The research developed in this study considers the Portuguese municipal scale. ${ }^{4}$ European and national elements, whose background can be found in the global framework of globalist neoliberalism, support the analysis developed here. The more comprehensive discussion focused on Europe aims to present the characteristics and the evidences of the rise 
of a right-wing nationalism, in order to frame the recent emergence of this phenomenon in Portugal, clearly amplified by the arrival of a Chega member at the Assembly of the Republic in the 2019 elections.

The information used to analyze the case of Portuguese municipalities is based on a set of secondary data of a quantitative nature obtained from the National Statistics Institute (INE), the High Commissariat for Migration (ACM), the Ministry of Internal Affairs (MAI), and Foreigners and Borders Service (SEF). Part of this data was obtained from the Pordata portal, which organizes and processes these data. The time frame extends from 2001 to 2019 due to the diversity of the variables chosen in the three defined dimensions: electoral, sociodemographic, and economic. The rationale for choosing the temporality of the various variables was based on obtaining the most recent information available (representation of the current situation) combined with data from a relatively closer earlier time (very recent dynamics and transformation trends). This resulted in the collection of data from the last two legislative elections in Portugal (2015 and 2019), from the last two Population Censuses (2001 and 2011), and from some social, demographic, and economic variables for other years between 2009/2010 and 2019 (Table 1).

For the framework analyses aiming at understanding the national electoral evolution, the two decades of the present century were considered, covering the last six legislative elections: 2002, 2005, 2009, 2012, 2015, and 2019. The variables included in the socio-demographic and economic dimensions intend to help to explain the municipal geographic pattern of votes for
Chega in 2019, interpreted somewhat as a "geography of discontent." The choice of variables considered the elements discussed in the previous section and took into account indicators that are in line with those that in Europe have been associated with the process analyzed here.

Evidently, these indicators were adapted to the specific situation of Portugal, not only due to the nature of the information available, but also to consider particular social and economic aspects. We emphasize, for example, the choice of the variable gypsy population residing in Portugal (Mendes, Magano and Candeias, 2014), considering that the speech of the elected deputy of Chega took advantage of a secular prejudice suffered by this population to construct an electoral narrative that reinforced stereotypes against those individuals. Therefore, it is relevant to understand possible effects of such process. The calculation for the gypsy population was based on a sample of 113 councils $^{5}$ in mainland Portugal, since there is no information available for the rest of them.

The set of 52 characterization and shortterm dynamics indicators (variation rates) was subjected to two statistical analyses using the software IBM SPSS 24: Pearson's correlation and multiple linear regressions. Although a correlation matrix of all variables was built, the vector that included the correlation of each indicator with the percentage of votes obtained by Chega in the 2019 legislative elections, considered as the dependent variable, was retained as the fundamental analysis process. The variables with the highest (in module) and most significant correlation were considered for analysis, using correlation coefficients (R) higher than 0.34 as a reference. 
Table 1 - Variables used in correlation and multiple regression analysis

\begin{tabular}{|c|c|c|}
\hline Dimension & Variable & Year \\
\hline \multirow{3}{*}{ Electoral } & $\%$ of valid votes for Chega & 2019 \\
\hline & $\%$ and rate of variation of valid votes (PS, PSD*, PCP**, PNR, CDS*, IL, PAN and BE) & 2015-2019 \\
\hline & $\%$ and rate of abstention variation & 2015-2019 \\
\hline \multirow{17}{*}{ Sociodemographic } & $\%$ Resident gypsy population*** & 2014 \\
\hline & $\%$ Female population & 2011 \\
\hline & $\%$ Illiterate Individuals**** & 2011 \\
\hline & $\%$ Individuals with schooling up to the $9^{\text {th }}$ grade & 2011 \\
\hline & $\%$ Individuals with secondary education & 2011 \\
\hline & $\%$ Individuals with higher education & 2011 \\
\hline & $\%$ Illiterate individuals and schooling with up to $9^{\text {th }}$ grade & 2011 \\
\hline & $\%$ Young resident population ( $15-29$ years) & 2011 \\
\hline & $\%$ Adult resident population (30-64 years) & 2011 \\
\hline & $\%$ Elderly resident population (65 and over) & 2011 \\
\hline & $\%$ Foreign population & 2019 \\
\hline & $\%$ Non-EU foreign population & 2019 \\
\hline & Variation rate Foreign population & 2010-2019 \\
\hline & Variation rate Non-EU foreign population & 2010-2019 \\
\hline & Variation rate Total resident population & 2001-2011 and 2009-2019 \\
\hline & Ageing index & 2001, 2011, 2015 and 2019 \\
\hline & Variation rate Aging index & 2015-2019 and 2011-2019 \\
\hline \multirow{9}{*}{ Economic } & \% Employed population in the secondary sector & 2001 and 2011 \\
\hline & $\%$ Unemployed $* * * * *$ & 2011, 2015 and 2019 \\
\hline & $\%$ (index number) Purchasing power per capita & 2017 \\
\hline & Beneficiaries of Social Insertion Income & 2015 and 2019 \\
\hline & $\%$ Employed population & 2001 and 2011 \\
\hline & Variation rate Unemployed & 2011-2015 and 2015-2019 \\
\hline & Variation rate Beneficiaries of Social Insertion Income & 2015-2019 \\
\hline & Variation rate Employed population & 2001-2011 \\
\hline & Variation rate Employed in the secondary sector & 2001-2011 \\
\hline
\end{tabular}

Sources: INE, SEF, ACM, MAI.

* The PSD and CDS parties ran in the 2015 elections as a coalition. Thus, we consider the two parties together for the 2015-2019 variation.

** The PCP party runs under the acronym CDU in coalition with a small ecological party that has never run for elections alone.

*** Data existing only for 113 municipalities in mainland Portugal; the remaining municipalities were excluded from the calculation of this correlation, which therefore considers only 113 units of analysis.

**** Data on education levels refer to individuals aged 15 or over.

$* * * * *$ The unemployment figure includes only unemployed people registered in employment and vocational training centers and not the total number of unemployed people. 
The correlation analysis was repeated considering only the 109 municipalities in the southern half of Portugal, given the relevance of an analysis that considered in addition to the national group, only municipalities belonging to seven districts located in that area (Lisbon, Santarém, Portalegre, Évora, Setúbal, Beja, and Faro) because of the over-representation of votes for Chega detected there. This same analysis was carried out for the gypsy resident population considering only the 47 councils in this region that had such information.

Next, the variables were subjected to a multiple regression model in which the percentage of votes for Chega in the 2019 elections was still the dependent variable, and all other electoral, sociodemographic and economic variables were combined as independent variables. This model, which allows assessing how certain sets of independent (most significant) variables combine to "explain" the dependent variable, has been reproduced for the set of municipalities in the south.

The mapping of Chega's electoral results represents the municipal location quotients (LQ), ${ }^{6}$ which allows verifying the over- and under-representation of the results of this party by municipality in comparison with the national average (1.3\% of the votes). The spatialization of LQs was performed using ArcGIS 10.6 software.

The choice of the methodological strategy for the analysis of aggregated data (in political science, also known as "ecological methodology" or "ecological analysis") adopted here results from being the only one simultaneously possible and feasible to achieve our objectives. An eventual collection of individual data by a survey of Chega voters in 2019 would require a large amount of resources. In addition, it would be very uncertain that, if contacted by pollsters, these voters would agree to reveal their vote and would be sincere about their motivations.

Thus, individual data are territorially aggregated and correlated with the vote for Chega in the 2019 legislative elections, which was also used as a dependent variable in a multiple regression. These procedures are involved in the discussion about the "ecological fallacy" (Freire, 2001, pp. 33-43; King, 1997, pp. 3-34), whose risks in these cases are spurious correlations and collinearity between variables, respectively. The significant correlations considered for analysis $(R>0.34)$ did not reveal any signs of this problem and the correlation matrix of all independent variables did not point to a significant collinearity in most cases. Moreover, it is known that, in most analyses in social sciences and geography, it is common the existence of some degree of correlation between variables that does not affect the results of the final model, and may even assist in some interpretation processes.

\section{Chega in the Portuguese political party system: political discourse, electoral results, and interpretation}

The Portuguese political party system and the emergence of Chega

Until recently, the Portuguese party system remained essentially similar to the one formed after the Democratic Revolution 
of April 1974, which overthrew the fascist regime of the Estado Novo. In 1975, elections were held for a Constituent Assembly, which approved the Constitution of the Republic under the new regime. In 1976, the first legislative elections were held. In these two elections, the PS and PSD (then PPD, Popular Democratic Party) emerged as the two main parties in Portugal, consolidating themselves as the "center" of the regime, a situation that still prevails. Also, since 1975-76, the PCP and CDS-PP emerged alternately as the third and fourth parties, which remained so until 2009, when the Left Bloc overtook the PCP for the first time. In that year, the PCP was the fifth most voted party.

Until recently, the only important and consistent change to the system had been the appearance of the Left Bloc (LB) in 1999 (see Table 2). That year, it elected two deputies and in the following elections, it started a growth trend that placed it in the same order of magnitude as that of the PCP and CDS. However, in the 2015 legislative elections, the party system showed important signs of change. That year, an animalistenvironmentalist party elected one parliament member and managed to elect four in 2019. Also in 2019, three other parties elected their first member to Parliament, including Chega, which meant a significant diversification of the represented political formations.

In 2015, another aspect of the political party system changed. Since the Carnation Revolution of 1974, the governance of Portugal has been in the hands of the PS and the PSD alternately or in coalition, and sometimes in coalition with the CDS-PP. This group of parties was, until then, known as "the arch of governance" because they were the only ones that effectively governed. Until then, the PS had never agreed to form a coalition with parties to its left in the Parliament, nurturing, in a framework antagonistic to the PCP, a historical fracture that referred back to the end of the revolutionary period in 1975 . In addition, the existence of some stances regarded as incompatible in matters such as Portugal's international commitments, economic policy orientation, labor protection, or the level of state intervention in the economy have prevented possible coalitions, not only with the PCP, but also with the BE.

The 2015 legislative elections were held after a period of intense economic and financial crisis that triggered a neoliberal austerity response by the right-wing government (PSD-CDS coalition) and caused unemployment to skyrocket, reduced wages, and provided less social protection. So, the PS refused to support a right-wing minority government ${ }^{7}$ and for the first time negotiated a parliamentary support with the PCP and the Left Bloc for a minority government of its own. That party proposed to reverse, in a progressive and mitigated way, some policies imposed in the previous quadrennium, for example in the areas of wages, social protection, and urban transport. This fact the appointment for the first and only time in the history of Portuguese democracy of a prime minister not belonging to the political force that won the elections, but with the support of a majority negotiated in Parliament - is the third element of rupture associated with the 2015 elections (Freire, 2017).

In the Portuguese Republic that emerged from the Revolution of April 25, 1974, voters elect by universal and direct suffrage the deputies that make up the Assembly of the 
Table 2 - Political parties with parliamentary representation in 2019

\begin{tabular}{|c|c|c|c|c|}
\hline Party & Ideology & $\begin{array}{l}\text { Vote in } 2019 \\
\qquad(\%)\end{array}$ & $\begin{array}{c}\text { No. of } \\
\text { deputies in } \\
2019\end{array}$ & $\begin{array}{l}\text { Parliamentary } \\
\text { representation } \\
\text { since }\end{array}$ \\
\hline Chega & Nationalist and Populist Right & 1.29 & 1 & 2019 \\
\hline $\begin{array}{l}\text { National Renewal } \\
\text { Party (PNR)* }\end{array}$ & Conservative Nationalist Right & 0.33 & 0 & * \\
\hline Liberal Initiative & Right-wing liberalism in all domains & 1.29 & 1 & 2019 \\
\hline CDS-PP & $\begin{array}{l}\text { Conservative Right - Christian } \\
\text { Democracy }\end{array}$ & 4.42 & 5 & 1976 \\
\hline $\begin{array}{l}\text { Social Democratic } \\
\text { Party (PSD) }\end{array}$ & Center-Right Economic Liberalism & 27.76 & 79 & 1976 \\
\hline $\begin{array}{l}\text { People-Animals- } \\
\text { Nature (PAN) }\end{array}$ & $\begin{array}{l}\text { Animalist party with an inclination } \\
\text { towards the left }\end{array}$ & 3.32 & 4 & 2015 \\
\hline Socialist Party (PS) & $\begin{array}{l}\text { Democratic socialism/social-democracy } \\
\text { (center-left) }\end{array}$ & 36.34 & 108 & 1976 \\
\hline Free & $\begin{array}{l}\text { Left libertarian with tendency towards } \\
\text { democratic socialism }\end{array}$ & 1.09 & 1 & 2019 \\
\hline Left Bloc (BE) & $\begin{array}{l}\text { Left libertarian with tendency towards } \\
\text { democratic socialism }\end{array}$ & 9.52 & 19 & 1999 \\
\hline $\begin{array}{l}\text { Portuguese } \\
\text { Communist Party } \\
(\mathrm{PCP})^{* *}\end{array}$ & Communism & 6.33 & 12 & 1976 \\
\hline
\end{tabular}

Source: prepared based on information from party websites and the Ministry of Internal Administration (SGMAl, 2019)

* The PNR never elected members of the Parliament. It was included in this list because of its ideological proximity to Chega and because the voting correlation of these two parties was greater than that of any party with parliamentary representation with Chega.

** Since 1987, the PCP has run for national elections associated with a small ecologist party, the PEV, which has never run on its own in legislative elections.

Republic (also known as "Parliament"). These deputies are included in the lists of political parties running for each election. These lists are organized by district constituencies, ${ }^{8}$ circles from the autonomous regions of the
Azores and Madeira, and emigration. Each constituency elects a number of deputies determined according to the number of voters (except for emigration) using the proportional method of Hondt. 
The recent emergence of Chega and of other small parties that elected members of the Assembly of the Republic can be regarded as the result of a trend of electoral erosion of the central parties in the political system of European countries. This electoral erosion has occurred concomitantly with the rise of nationalist right-wing parties and parties with thematic causes, such as environmentalism and animalism, and sometimes also of left-wing parties that challenge neoliberal hegemony. This has resulted, for example, in the Greek and French socialist parties having ceased to have their traditional central roles in the system and becoming secondary actors.
In Portugal, this trend has also manifested itself in legislative elections since the beginning of the $21^{\text {st }}$ century. The total number of votes for the PS and PSD decreased from almost $80 \%$ of the valid votes in 2002 to $67.4 \%$ in 2019 (see Figure 1).

Note that considering valid votes as a reference reflects in higher percentages than considering voters (which also include blank and null ballots) or registered voters. In the case of voters, the percentages decrease by two to three percentage points compared to valid votes. However, in case the reference is registered voters, the sum of the votes for the PS with that for the PSD is $48.6 \%$ in 2002 and $31.1 \%$ in 2019.

Figure 1 - Erosion of the political party core in Portugal at the beginning of the 21st century

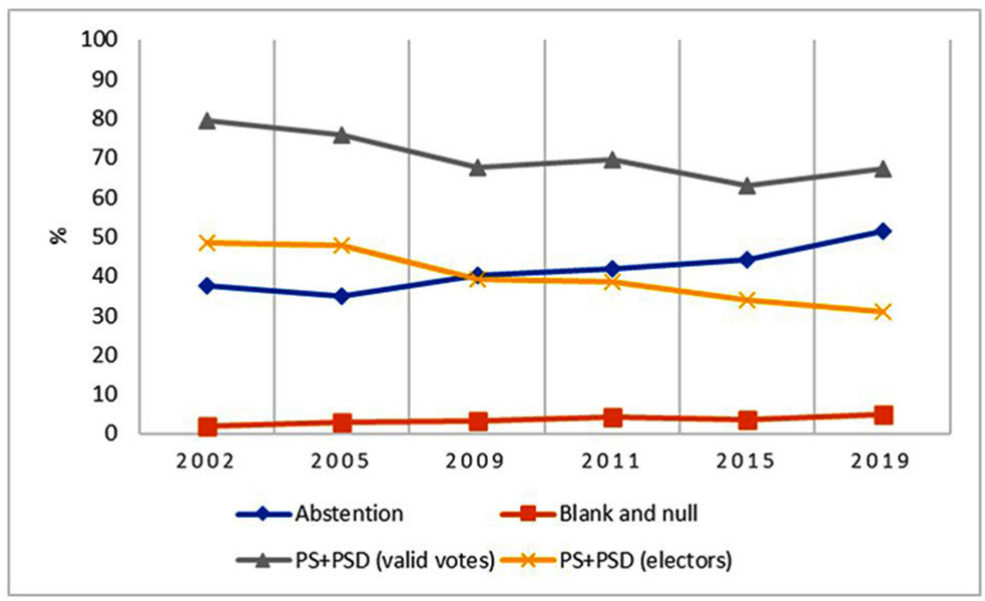

Source: Ministry of Internal Administration (SGMAI, 2019). 
In this context, the fact that Chega ran for the first time in the 2019 legislative elections and immediately elected its founding president, André Ventura, as a deputy by the Lisbon electoral district is of particular significance, because Chega is a party with a speech and political proposals that can be framed within the nationalist and populist right, which has grown rapidly in many European countries. In its Founding Political Manifesto (Chega, s/d), the party assumes itself as "national, conservative, liberal, and personalist." In some recent polls, its voting intentions have grown much higher than the $1.29 \%$ it previously had at the national level.

In Portugal, until recently, the antisystem and/or populist vote with a significant dimension and parliamentary representation was the left-wing vote for the Portuguese Communist Party (PCP) and for the Left Bloc (considering a broad sense of populism), which together obtained 10 to $15 \%$ of the votes (with fluctuations) in the elections for the Assembly of the Republic.

The PCP, founded in 1921 with a MarxistLeninist orientation, can be regarded as a typically anti-system party. It makes a wide range of criticisms and alternative proposals to the status quo, with emphasis on economic policy guidelines and the interventionist role of the State. The Left Bloc, which has focused its criticism not so much on the system but on its problems and the life difficulties of various segments of the population, is a result of the re-foundation and merging of small parties of the so-called "radical left" that incorporated "new" orientations associated, for example, with the diverse dimensions of subordination (gender, ethnicity, sexual orientation, age structure) that go beyond exploitation based on the positioning of individuals in the economic system (social classes) and that value identity aspects.

In their speeches, both call attention to the great inequalities existing in Portugal and sometimes call for an opposition between ordinary people (the people, in a more monolithic sense in the case of the PCP and in a more diversified sense in the case of the $\mathrm{BE})$ and the ruling classes and plutocratic interests, which can be framed within the left dyadic populism. Moreover, in an analysis of the electoral programs of the main parties between 1995 and 2015, Lisi and Borghetto (2018) classified as populist $29.4 \%$ of the paragraphs of the PCP's program and $17.9 \%$ of the paragraphs of the Left Bloc program, compared to $18.6 \%$ and $4.3 \%$ of their programs in 2015 , respectively.

\section{Main aspects of Chega's proposals and electoral speech in 2019}

The identification of Chega as a party that is at the same time "national, conservative, liberal, and personalist" can be problematic, as some of these pillars are potentially conflicting with each other. For example, in its 2019 Political Program (Chega, 2019), the party defines itself as both liberal and conservative, which may be contradictory. This is ultimately not the case because Chega has an ultraliberal economic program and a conservative identity and customs views.

Regarding its proposals, the liberal dimension of Chega is mentioned at the beginning of its Founding Political Manifesto. It states that the party "was born to reduce the State to its minimal essential functions." This idea is specified in its 2019 Political Program, 
which advocates, for example, the extinction of the Ministry of Education so that the State has only an arbitration role in education, extending this logic to higher education, for which privatization of public universities is advocated. Similarly, it says that the State "should not, ideally, interfere as a provider of goods and services" in health and should not have positions in companies, without proposing an economic strategy.

However, the fact that has most famously distinguished Chega from the other parties, and that has had the most media impact, is its conservative and identity discourse. At the same time that it highlights the role of the Catholic Church in the structuring of European and Portuguese civilizations and praises a supposedly unified and static national identity, it stigmatizes some specific ethnic groups (e.g. gypsies) based on the replication of stereotypes.

Thus, in its Founding Political Manifesto, the party aims to "prohibit political and religious practices that offend the Portuguese legal system and the European cultural roots, in particular antisemitism, gender ideologies, the application of Sharia, excision, forced marriages of minors, inhibition of minors' attendance to minimum compulsory education, racism of any nature, among other current - and unpunished - practices in communities that, after all, benefit from State assistance without complying with the applicable legal and general provisions" (Chega, s/d). In these examples, in addition to mixing elements with diverse and even contradictory contents ("gender ideology" and "racism of any nature," but criticizing the support of the State to members of some communities, in addition to implicitly stigmatizing and even adopting a xenophobic attitude in relation to the gypsy community) and identifying challenges, the party is nonetheless not concerned with considering transformation trends and depreciate public policies that are empowering and towards social change.

In parallel, and also in line with what has been the discourse of the nationalist right in other European countries, Chega states that "it will prioritize its action in the fight against the 'politically correctness,' the corruption of interests, institutionalized censorship, illegal immigration, weaknesses in border control, and the growing impunity for organized and violent crime."

In fact, André Ventura rose to national political celebrity in 2017 , when, as part of his campaign as a candidate, by the PSD, to be president (mayor) of the municipality of Loures, he made statements in which spoke about the impunity of gypsies and stated that they lived almost exclusively of public subsidies. He also referred to them as being often generators of troubles, situation that media tend to report with some frequency (it was the case, for example, of the attack on a fire station in Borba in 2019 by a group of local gypsy people). ${ }^{9}$ Recently, regarding the COVID-19 epidemic, he proposed that a specific containment plan be adopted for the gypsy community (because supposedly there was a systematic violation of restriction rules imposed on the entire population by segments of the gypsy community, as reported by the media). ${ }^{10}$ This population has lived in Portugal for at least five centuries. The lack of social recognition has resulted, in the past and in the present, in practices and discourses of discrimination and racism 
that clearly have hindered processes of approximation between gypsies and the majority of the Portuguese population (Mendes, Magano and Candeias, 2014).

\section{Voting for Chega by municipality in 2019}

The vote for Chega in the legislative elections that took place on October 6, 2019, presents a surprising territorial pattern, judging by what has been the geography of the traditional division between the left and the right inherited from the foundation of the democratic regime. The right has been stronger in the North and the left has been stronger in the South. As early as 1975, this division resulted from the vote for the four parties that structured the democratic political party system. They presented a clear geographic distribution that has tended to keep its main characteristics, although they began to blur in the following legislative elections (Gaspar and André, 2018, pp. 160-164).

The vote for the PSD presented a strong North-South dichotomy, with some exceptions in the North of Alentejo and Algarve. This same dichotomy occurred with the vote for the CDS-PP, but with more dispersed areas of influence (due to the smaller size of this party) and a greater difficulty in penetrating the South (Gaspar, André and Honório, 2018, pp. 102-108). The PS presented a less concentrated pattern than that of the other three parties. The insertion was stronger in the Tagus Valley and in the Algarve, and also in industrial areas of the Center and the North Coast, also associated with urban voting. This has been one of its main characteristics. Note that the Left Bloc, which has asserted itself since 1999 , also has a concentrated voting in urban centers. For its part, the PCP vote was historically more concentrated than that of the other three parties mentioned, essentially in Alentejo and in some municipalities of the Lisbon metropolitan area, even in a context in which it has suffered a slow and prolonged trend of loss of electoral support.

The map of location quotients of the vote for Chega by municipality reveals precisely that it is in the South, up to the Tejo Valley (inclusively), that this new right-wing populist party obtains votes above its national percentage (Figure 2). This area extends to the municipalities of the west coast to the north of Lisbon, even to areas close to Coimbra and some municipalities of the Beira Interior, but with lower values than those recorded further south. The municipalities with the highest incidence of votes for Chega are mainly located in the Alentejo, especially in the inland, in the metropolitan area of Lisbon, in the Tejo Valley and in the central and western Algarve. This pattern coincides to some extent with that of the Portuguese Communist Party. This overlap with a party that is ideologically the opposite to Chega raises interesting questions for analysis. It should be emphasized, first of all, a common aspect of these two parties: both are regarded as phenomena that reflect discontent towards a system that fails in providing answers to people (e.g. parties known as "the arc of governance" up to 2015).

In addition, the vote for the PCP is usually classified as a "protest" vote (as well as the vote for the Left Bloc and other small parties). This has obvious resonances with the geography of discontent based on the vote for right-wing populist parties, based on clear phenomena of rejection of the system. 
Figure 2-Location quotients of the valid votes for Chega in the elections for the Assembly of the Republic, 2019

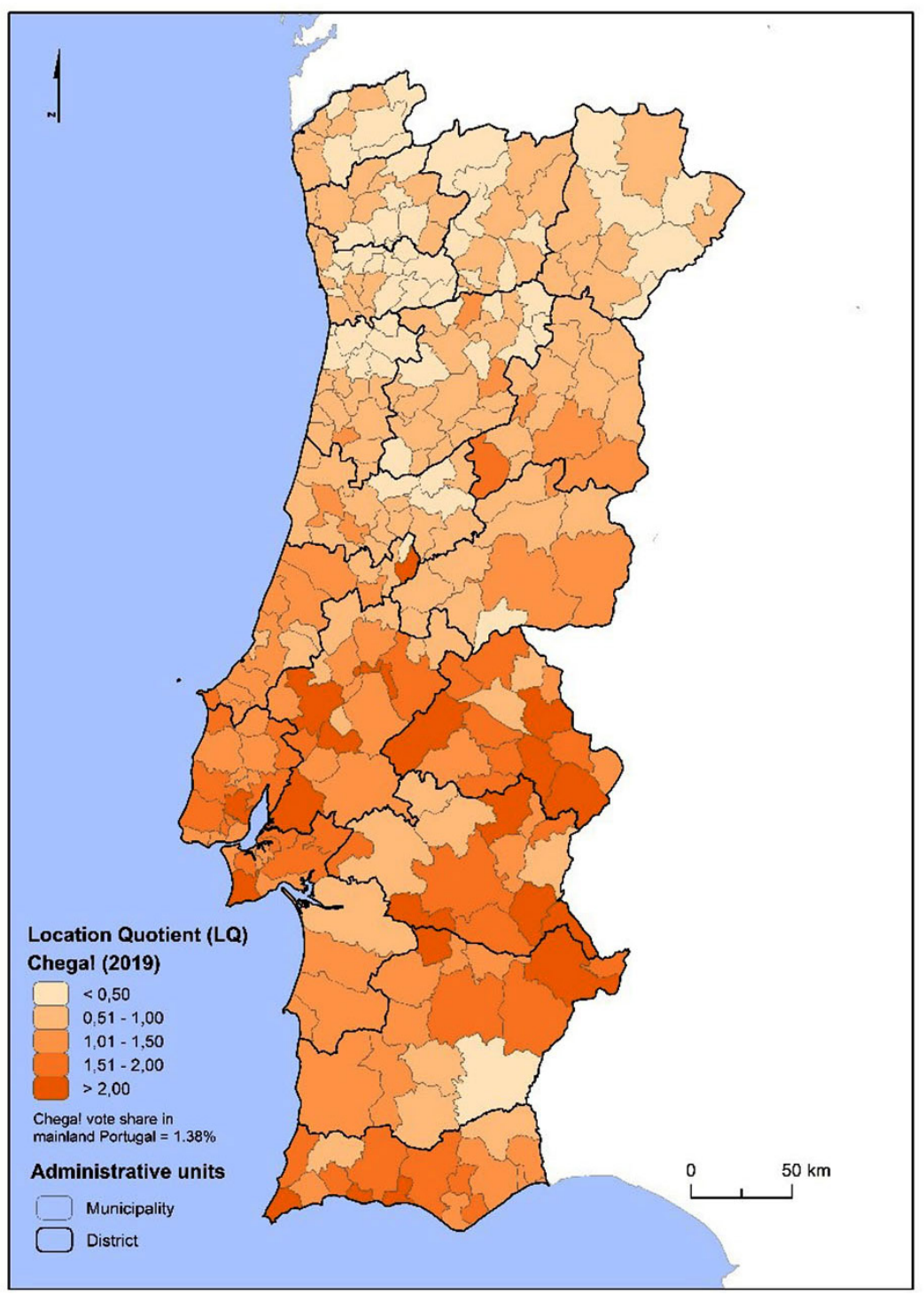


Explanatory hypotheses for the municipal voting standard for Chega: significant simple linear correlations and multiple regression with electoral, sociodemographic, and economic variables

The simple linear correlation between the percentage of votes for Chega by municipality in the October 2019 legislative elections and a set of electoral, sociodemographic and economic variables resulted in significant Pearson coefficient values for 13 variables (see Table 3). Unsurprisingly, the greatest correlation was with the vote for the National Renewal Party (0.56), a small nationalist rightwing party with extreme-right ideas established twenty years ago through the re-founding of a pre-existing dying small party; PNR had never managed to obtain electoral success or elect any member to the Parliament. Naturally, the programmatic similarity between both parties explains the strong correlation between the territorialization of their votes.

As mentioned in the analysis of the municipal voting map, the relatively high and positive correlation between the territorial patterns of voting for Chega and for PCP is noteworthy (the latter competes under the acronym CDU by colligating with a small ecological party, the PEV). Such a coefficient of correlation of 0.42 is the only positive and strong one of Chega with an important party in the Portuguese political system.

Table 3 - Significant correlations with municipal voting for Chega, mainland Portugal

\begin{tabular}{|l|c|}
\hline & Pearson's Correlation \\
\hline \% National Renewal Party (PNR) (2019) & $0.555^{* *}$ \\
Abstention variation rate 2015-2019 & $0.533^{* *}$ \\
\% of population aged 15 and over with secondary schooling (2011) & $0.470^{* *}$ \\
$\%$ of gypsy population & $0.457^{* *}$ \\
\% vote for the Portuguese Communist Party-PEV-2019 party & $0.420^{* *}$ \\
$\%$ of foreign population (2019) & $0.342^{* *}$ \\
\hline \% vote for the Social Democratic Party (PSD) (2019) & $-0.551^{* *}$ \\
\% employed population in the secondary sector (2011) & $-0.481^{* *}$ \\
Aging index variation rate (2011-2019) & $-0.466^{* *}$ \\
Aging index variation rate (2015-2019) & $-0.410^{* *}$ \\
Left Bloc (BE) vote variation rate (2015-2019) & $-0.43^{* *}$ \\
$\%$ of population aged 15 and over with schooling up to the 9th year & $-0.397^{* *}$ \\
Socialist Party (PS) vote variation rate (2015-2019) & $-0.362^{* *}$ \\
\hline
\end{tabular}

** Significant correlation at 0.01 (bilateral).

Source: authors' calculations using data from INE and MAI. 
Conversely, the municipal voting pattern for Chega in 2019 also has a relatively strong, but negative $(-0.55)$ correlation with the vote for the PSD, that is, the higher the concentration of votes for the PSD, the less votes for Chega. It also has relevant negative correlations with the 2015-2019 variation of votes for the Left Bloc $(-0.43)$ and PS $(-0.36)$. However, this is expected: the higher the votes for Chega, the less the growth of the Bloc and PS, parties whose principles are opposed to those of Chega.

Finally, still in the domain of electoral variables, there was a strong correlation (0.53) between the variation of abstention in 20152019 and the vote for Chega. This indicates that the party achieved a greater penetration in municipalities where the percentage of voters who give up voting has grown the most. Bearing in mind that abstention in Portugal may often be interpreted as a passive protest, in the sense of giving up in face of the system, this is another indicator that associates voting for Chega with voters' discontent and with protest votes, along with the correlation with the vote for the PCP.

Among the socio-demographic variables, the strongest correlation (0.47) occurs with the percentage of population that completed secondary education; inversely, there is a negative correlation with the percentage of population with an education level below the 9th grade. Considering that in Europe the vote on the populist right tends to be higher among the less educated, these data do not fully support such relation for the Portuguese case. The same idea emerges from the important negative correlations of voting for Chega by municipality and the variation in the aging index between 2011 and 2019 (-0.47\%) and between 2015 and 2019 (-0.41), since studies at a European level have indicated a trend towards a greater penetration of this type of party among older voters.

The positive correlations of voting for Chega with the percentage of resident foreigners (0.34) and above all with the percentage of the gypsy population (0.46) are not surprising, taking into account what is known of other countries. This aspect is particularly significant due to the emphasis given by the party leader to issues related to this ethnicity since he asserted itself in the Portuguese political-media space.

Of the variables of economic nature tested, only the percentage of population employed in the secondary sector has a relevant correlation $(-0.48)$ with the vote for Chega by municipality. However, this is an important variable in light of what is already known about the geography of discontent in Europe, as the vote for the anti-system right is associated with a long-term economic decline in industrial regions.

These elements allow confirmation of a geographic association between the Chega vote and the political-electoral discontent due to its overlapping to both the communist vote and the recent rise in abstention. This is related to the presence of a foreign population and a Portuguese gypsy population. ${ }^{11}$ At the same time, in places where there is more industry, the vote for Chega tends to be lower.

The coincidence between the greater electoral penetration of Chega and the presence of foreign population and the Portuguese gypsy population is in line with some data from the 2019 Portuguese Electoral Study analyzed by Magalhães (2020). According to the author, an overwhelming 
majority (88\%) of voters of Chega considers that "minorities should adapt to the customs and traditions of Portugal" (compared to $63 \%$ among voters of other parties in 2019), while $62 \%$ argued that having Portuguese ancestors is "very important" to be "truly Portuguese" (compared to $36 \%$ among voters of other parties in that same year). However, this coincidence must be interpreted with caution because we are facing a very recent phenomenon and because, in that same Electoral Study, $88 \%$ of the voters of Chega stated that "immigrants are good for the Portuguese economy" (compared to 63\% of voters of other parties) and $25 \%$ stated that immigrants increase crime rates, less than the $28 \%$ of voters of the other parties and significantly less than the $35 \%$ of abstainers who expressed the same opinion.

As a complement to the analysis of Pearson's correlation coefficients, the multiple regression model built to test the association of the percentage of votes obtained by Chega with electoral, sociodemographic, and economic variables, now considered jointly, essentially confirms the way by which some already highlighted political and sociodemographic variables combine to explain the municipal voting pattern in Chega (Table 4).

In political terms, the percentage of votes for the PNR and the abstention rate variation continue to stand out. They are assumed to be the variables with the greatest explanatory power, and which are incorporated in the first two steps of the model. This confirms the ideological dimension of the Chega vote (the extreme right populist nationalism sharing space with the PNR) and the element of protest and discontent with the system, which can be inferred considering the contribution of the variation in the percentage of abstention to explain the Chega results. It should be noted that the absence of other political variables

Table 4 - Stepwise multiple regression (successive results) (Dependent variable: percentage of votes for Chega in the municipalities of mainland Portugal in the 2019 Legislative Elections)

\begin{tabular}{|c|l|c|c|c|}
\hline $\begin{array}{c}\text { Model } \\
\text { (stage) }\end{array}$ & \multicolumn{1}{|c|}{ Variable } & R & $\mathbf{R}^{2}$ & $\begin{array}{c}\text { Adjusted } \\
\mathbf{R}^{2}\end{array}$ \\
\hline 1 & \% National Renewal Party (PNR) (2019) & 0.555 & 0.308 & 0.305 \\
2 & Abstention variation rate (2015-2019) & 0.670 & 0.448 & 0.444 \\
3 & Aging index variation rate (2011-2019) & 0.703 & 0.495 & 0.489 \\
4 & \% of Beneficiaries of Social Insertion Income (2015) & 0.735 & 0.541 & 0.534 \\
5 & \% of population aged 15 and over with secondary education (2011) & 0.760 & 0.577 & 0.569 \\
6 & \% of Beneficiaries of Social Insertion Income (2015) & 0.785 & 0.616 & 0.608 \\
7 & Employed in the secondary sector variation rate (2001-2011) & 0.800 & 0.640 & 0.630 \\
\hline
\end{tabular}

Note: according to the $\mathrm{F}$ test, all variables included in these steps are significant at 0.05 .

Source: authors' calculations using data from INE and MAI. 
in the set of variables considered as more significant in this multivariate model, with emphasis on the percentages of votes for the PSD and PCP-PEV, ${ }^{12}$ which record a relatively high correlation coefficients, although with different inclinations, with the percentage of votes obtained by Chega in 2019, justifies further refinement in the analysis of these simple links. Such a study is worth conducting in the future with the support of more information on effective voting transfers. Even so, it is worth noting that the correlations between the percentages of votes obtained by these two parties in 2019 and the variation in the percentage of abstention between 2015 and 2019 are stronger (although positively in the case of the PCP-PEV and negatively in the case of PSD) than the correlations between the aforementioned percentages and the percentage of voting for Chega in that election. As the variable corresponding to abstention is one of the strongest in the model, its redundancy with the percentages of votes for the PSD and PCP-PEV not only helps to explain the reduction in their statistical significance in the multiple regression, but also draws attention to the fact that any links or transfers of votes between these constituencies implies an analysis of the role of abstention in the process.

Regarding the sociodemographic and economic dimensions, the results of the model confirm the apparent originality of the Chega voters' profile in face of what studies carried out on similar parties in other European countries have detected (younger voters with somewhat higher qualifications in the case of Portugal). However, the fact that it is a "pioneering vote" (it was first time the party ran in elections) justifies caution in this comparative analysis. Still regarding the social sphere, in the combined framework of explanations for the vote in Chega, the model incorporates, albeit indirectly (via variables associated with Social Insertion Income), the proportion of the gypsy population ${ }^{13}$ and, broadly, the proportion of population in a situation of dependency and strong social disadvantage. Indeed, a speech with a xenophobic character particularly aimed at the gypsy ethnic group, which, as we have seen, systematically posits an association with subsidy dependency, seems to find echo among voters residing in municipalities where the population that benefits from the RSI is higher. It is easy to associate this situation with gypsies, even if they mean a very low percentage of the group of beneficiaries.

\section{The southern half of Portugal as Chega's} preferred electoral landscape: brief contributions to an interpretation

When we consider the correlations between the vote for Chega by municipality and the variables analyzed only in relation to the municipalities in the southern half of Portugal, it is clear that significant correlations with variables of an electoral nature lose weight at expenses of correlations with socioeconomic variables (see Table 5). In that part of Portugal, where Chega obtained the highest results, the correlation with the communist vote is no longer important and the correlation with the PNR vote is weaker. The correlation with the presence of the gypsy population is even stronger than that of the country's total, but the correlation with the presence of a foreign population is no longer relevant. 
Table 5 - Significant correlations with municipal voting for Chega in Portugal's southern municipalities

\begin{tabular}{|l|c|}
\hline & Pearson's Correlation \\
\hline \% of gypsy population & $0.533^{* *}$ \\
\% of Beneficiaries of Social Insertion Income (2019) & $0.472^{* *}$ \\
\% of Beneficiaries of Social Insertion Income (2015) & $0.439^{* *}$ \\
\% Unemployed population (2019) & $0.375^{* *}$ \\
Variation rate for PAN (2015-2019) & $0.361^{* *}$ \\
\% Abstention (2019) & $0.354^{* *}$ \\
\% young population 15-29 years (2011) & $0.350^{* *}$ \\
\% National Renewal Party (PNR) (2019) & $0.349^{* *}$ \\
\hline \% employed population in the secondary sector (2011) & $-0.385^{* *}$ \\
Aging index (2019) & $-0.351^{* *}$ \\
\hline \multicolumn{2}{|c}{$\%$ of votes for Chega (2019): Dependent variable } \\
\hline
\end{tabular}

** Significant correlation at 0.01 (bilateral).

Source: authors' calculations using data from INE and MAI.

At the same time, the variables most related to economic difficulties gain weight. There are significant correlations with the percentage of beneficiaries of Social Insertion Income (poor population) and the unemployed population, and a negative correlation with industrial employment. In addition, significant correlations with education levels disappear, and such correlations emerge with the young population (positive) and the aging index (negative).

These particularities of Chega's results in areas where it obtained a more expressive voting seem to indicate a greater weight of economic problems in voters' motivations. However, such problems can be interpreted as related to the presence of recent immigrant or gypsy populations, as is conveyed by the rightwing triadic populist discourse. In addition, as we mentioned earlier, the stereotype that associates Social Insertion Income with people of gypsy ethnicity highlights precisely this type of connections.

The multiple regression applied to the same variables, considering the percentage of votes for Chega as the dependent variable, for the set of municipalities in the southern half of Portugal (Table 6) confirms the greater weight of variables related to economic difficulties, with emphasis on the RSI and the association with industrial employment, which follows an inverse relation (the more relevant this association, the lower the percentage of votes for Chega). 
Table 6 - Stepwise multiple regression (successive results)

for municipalities in the south of Portugal

(Dependent variable: percentage of votes for Chega in the 2019 Legislative Elections)

\begin{tabular}{|c|l|c|c|c|}
\hline $\begin{array}{c}\text { Model } \\
\text { (stage) }\end{array}$ & \multicolumn{1}{|c|}{ Variable } & $\mathbf{R}$ & $\mathbf{R}^{2}$ & $\begin{array}{c}\text { Adjusted } \\
\mathbf{R}^{2}\end{array}$ \\
\hline 1 & \% of Beneficiaries of Social Insertion Income (2019) & 0,472 & 0,223 & 0,215 \\
2 & \% National Renewal Party (PNR) (2019) & 0,632 & 0,400 & 0,389 \\
3 & Left Bloc (LB) variation rate (2015-2019) & 0,684 & 0,468 & 0,453 \\
4 & \% employed population in the secondary sector (2011) & 0,707 & 0,500 & 0,481 \\
5 & \% of Beneficiaries of Social Insertion Income (2019) & 0,726 & 0,526 & 0,504 \\
6 & PAN variation rate (2015-2019) & 0,740 & 0,547 & 0,521 \\
7 & \% of vote for the PCP-PEV (2019) & 0,753 & 0,566 & 0,536 \\
\hline
\end{tabular}

Note: according to the $\mathrm{F}$ test, all variables included in these steps are significant at 0.05 .

Source: authors' calculations data from INE and MAI.

However, in this multivariate model, the electoral variables make interesting contributions. The percentage of votes for the PNR remains as the strongest indicator, albeit losing meaning in view of the model that considers all municipalities in Portugal. In addition, as elements of the combined explanation for the percentage of votes obtained by Chega in the municipalities of the southern half of Portugal, the model integrates the variation rates (2015-2019) of votes for two relatively young parties (Left Bloc and PAN). These votes can be regarded as protest votes and are often associated with particular rights (e.g., of specific social groups, of animals). Note that Pearson's simple linear correlations between variations in the percentage of each of these parties and the percentage of Chega have a different meaning. There is a negative value in the case of $\mathrm{BE}$ (geographic patterns have elements of antithesis to each other) and positive in the case of the PAN (the patterns show overlapping elements). Finally, the percentage of votes for the PCP-PEV is the last independent variable of the model. It confirms, for the area of Portugal where the Communist Party has traditionally been more established, some proximity to the Chega voting pattern compared to the value obtained for the set of municipalities in Portugal. However, such proximity has to be analyzed in connection with other variables considering the decrease in Pearson's correlation between these two indicators. 


\section{Conclusion}

Chega began to assert itself in the Portuguese political party space showing some specific characteristics in comparison to similar phenomena in other European countries. One of these characteristics is that its political program is radically neoliberal from an economic point of view and marked by contradictions regarding the insertion of the Portuguese economy in international arrangements that are potentially harmful to parts of the population. For example, regarding the European project, the explicit support written in party documents and declared by its leader is contradicted by criticisms regarding the control of the national economy by the most advanced EU countries, which, among others, could imply an action of recovery of autonomy in currency issuing (Marchi, 2020).

The discourse axis of Chega that most resembles this new nationalist right is the identitarian, showing a clear and strong conservative concern. This identity dimension, along with the dichotomy between the people and a ruling class considered to be oligarchic, and between the "true" Portuguese and foreigners and members of non-Portuguese ethnic groups (in particular the gypsy population), makes Chega an example of the right-wing triadic populism that has grown in Europe in recent years.

The electoral geography of Chega, at least in the legislative elections of October 2019 , proved to be counterintuitive in relation to what has been the territorial pattern of right-wing parties in Portugal. This is because Chega's greatest penetration has occurred in areas (southern half of Portugal) where the left-wing vote, especially the communist one, has historically had the greatest strength.

The positive correlation of the vote for Chega by municipality with the vote for the PCP (represented by the CDU), considering mainly the growth of abstention, confirms the idea that Chega's voters are mainly from socioeconomic groups that are unhappy with, or resentful of, the difficulties of daily life and the political party system, as has happened in other European countries. Such discontent, which also takes advantage of some electoral demobilization in other fields, both on the right (in the case of the CDS, a Christian and conservative party) and on the left (for example, in the area of the PCP), also appears related to identity issues. This emerges through strong correlations with the percentage of foreign population and, above all, the gypsy population in each municipality.

It should be noted that the sociodemographic variables most correlated with the vote for Chega point to a somewhat atypical sociology of its voters compared to what has been found in studies on this phenomenon in most European countries. This is because there are negative correlations with the less educated population and with the recent increase in the aging index. This atypical sociology is corroborated by the multiple regression model applied to the set of electoral, social, and economic variables used to explain the percentage of votes for Chega in Portuguese municipalities.

Less obviously, there is also a relationship between the territorial pattern of voting for Chega and variables related to the lack of economic dynamism. Actually, there is less penetration of that party in areas where we find a higher employment rate in industry 
and a stronger presence in the municipalities with the highest percentages of population that benefits from the Social Insertion Income, situation that becomes clearer in the case of the southern half of Portugal, where Chega had more votes.

These results show that the geography of the vote for Chega is part of what has been called in Europe the geography of discontent, or resentment, with an electoral base that responds to the same type of motivations. Voters in this new party have sociodemographic features somewhat atypical in the European context, but their territorial distribution has a significant correspondence with that of variables characteristic of identity concerns and, to a lesser extent, of economic difficulties.

It should be noted that this attempt to outline a geography of discontent in Portugal took place when the phenomenon of a possible electoral revolt associated with the problems of sizeable population sectors was still embryonic. It began to become visible precisely in the elections whose results we analyze here. Considering that the whole context leads to the supposition of a possible rapid growth of Chega, the territorial pattern of its voting and some characteristics of its voter base may easily change in future elections.

Finally, it is necessary to mention two analysis limitations that justify further exploration in later works. First, the non-inclusion of socio-professional variables, namely considering professional status, disregards a potentially important complementary dimension to explain the geographic voting patterns detected. Secondly, the internal geographical diversity of many municipalities in demographic, social, and economic aspects, with emphasis on the largest and most urbanized ones, probably translates into lower correlation values between these types of variables and the electoral results of Chega. To obtaining clearer and more robust results one could treat information at the submunicipal level ("freguesias," communities), at least for a sample of municipalities where Chega obtained more expressive results. Unfortunately, because we initially felt the need to use an approach that combined more general components with a slightly larger scale of analysis (municipality), there was no longer any space left to detail the freguesia level, which we may do in a future study. 


\section{[I] https://orcid.org/0000-0003-3206-5522}

Universidade de Lisboa, Instituto de Ciências Sociais e Centro de Estudos Geográficos. Lisboa, Portugal.

paulo.madeira@campus.ul.pt

\section{[II] https://orcid.org/0000-0001-5935-9390}

Universidade de Lisboa, Instituto de Ciências Sociais e Centro de Estudos Geográficos. Lisboa, Portugal.

katielle@campus.ul.pt

\section{[III] https://orcid.org/0000-0002-0976-044X}

Universidade de Lisboa, Instituto de Geografia e Ordenamento do Território, Centro de Estudos Geográficos. Lisboa, Portugal.

jmalheiros@campus.ul.pt

Translation: this article was translated from Portuguese to English by Rafael Rocca.

\section{Acknowledgement}

The authors would like to thank Diogo Gaspar Silva for the technical support in handling statistical information and plotting the map, and Manuela Mendes for the useful information she provided. We are also thankful to the Center for Geographical Studies of the Institute of Geography and Spatial Planning of the University of Lisbon, funded by the Foundation for Science and Technology (FCT, IP), under the grants UIDB/GEO/00295/2020 and UIDP/GEO/00295/2020, for the financial support for the English translation of the manuscript. Finally, the authors express their appreciation to the anonymous reviewers for the valuable comments and suggestions, although the contents of the study and the ideas expressed in it are the sole responsibility of its authors. We also thank Rafael Rocca for the translation of the manuscript.

\section{Notes}

(1) Although Chega was the first political force within this ideological area to elect a deputy, this type of speech and orientation can also be found at the core of the National Renewal Party (PNR), a small political force that has run for parliamentary elections since 1999, despite never having managed to elect any parliamentarian.

(2) Available at: http://www.resultadoseleitorais.azores.gov.pt/Resultados.aspx. Accessed on: December 14, 2020.

(3) In the original: "More concretely, we define populism as a thin-centered ideology." 
(4) For reasons of analysis simplification, only the 278 municipalities in mainland Portugal were considered. This implied excluding the 30 municipalities in the insular autonomous regions of the Azores and Madeira.

(5) A council is a synonym for municipality.

(6) The LQs result from dividing the percentage of votes obtained by Chega in each municipality by the percentage of votes it obtained at a national level. This allows identifying the level of overrepresentation (values above the unit) or underrepresentation (values below the unit) of the votes recorded in each municipality.

(7) The PSD and the CDS, which governed Portugal in the previous legislature (2011-2015), ran as a coalition in the 2015 elections under the designation "Portugal à Frente" ("Portugal forward") and obtained the highest number of votes. This meant, within the framework of the principles of Portuguese politics, that the leader of this coalition was the first to be called in order to form a government.

(8) In Portugal, districts are territorial units of a subregional scale created for administrative purposes.

(9) Interview with André Ventura (Bugalho, 2017).

(10) Interview with André Ventura (Banha, 2020).

(11) Some foreign gypsies live in Portugal, mainly of Romanian nationality, but their number is insignificant compared to that of the Portuguese gypsy population.

(12) Note that the Pearson's correlation coefficient resulting from the association between the percentages obtained by these two parties at the municipal level in the 2019 legislative elections is quite high, although with a negative sign (-0.791). This indicates some redundancy between both patterns.

(13) Note that the variable referring to the gypsy population cannot be incorporated into these regression models because, as we have seen, there are only data for 113 units of analysis (municipalities) and not for all 278 units whose data are available for the remaining variables.

\section{References}

BANHA, A. T. (2020). Reportagem com André Ventura: “Chega quer plano de confinamento 'específico' para comunidade cigana”. Jornal / online, 4/5. Disponível em: https://ionline.sapo.pt/ artigo/695215/chega-quer-plano-de-confinamento-especifico-para-comunidade-cigana. Acesso em: 27 ago 2020 .

BONIKOWSKI, B. (2017). Ethno-nationalist populism and the mobilization of collective resentment. The British Journal of Sociology, v. 68, n. S1.

BUGALHO, S. (2017). Reportagem com André Ventura: "Os ciganos vivem quase exclusivamente de subsídios do Estado". Jornal / online, 17/1. Disponível em: https://ionline.sapo.pt/artigo/572563/ andre-ventura-os-ciganos-vivem-quase-exclusivamente-de-subsidios-do-estado. Acesso em: 27 ago 2020.

CHEGA (2019). Programa Político 2019. Disponível em: https://partidochega.pt/programapolitico-2019/. Acesso em: 27 ago 2020. 
CHEGA (s/d). Manifesto Político Fundador. Disponível em: https://partidochega.pt/manifesto/. Acesso em: 19 ago 2020.

DIÁRIO DE NOTíCIAS (2019). Ciganos, imigrantes e prisões. O que diz André Ventura. Disponível em: https://www.dn.pt/poder/ciganos-imigrantes-e-prisoes-o-que-diz-andre-ventura-11379814. html. Acesso em: 19 ago 2020.

DIJKSTRA, L.; POELMAN, H.; RODRÍGUEZ-POSE, A. (2019). The geography of EU discontent. Regional Studies, v. 54, n. 6, pp. 737-753. DOI: 10.1080/00343404.2019.1654603.

FERRÃO, J. (2019). "Para uma geografia com todos os lugares: reflexões a partir do caso europeu". In: FERREIRA, A. et al. Produção do espaço - Emancipação social, o comum e a "verdadeira democracia". Rio de Janeiro, Consequência Editora.

FREIRE, A. (2001). Mudança eleitoral em Portugal: clivagens, economia e voto em eleições legislativas, 1983-1999. Oeiras, Celta.

(2017). Para lá da "Geringonça": o governo de esquerdas em Portugal e na Europa. Lisboa, Contraponto.

FREIRE, A. (2019a). Populismo (I): Um Programa Analítico. A Vaca Voadora, 23 de outubro. Disponível em: https://avacavoadora.pt/populismo-i-um-programa-analitico/. Acesso em: 16 dez 2020.

(2019b). Populismo (II): Um Programa Político para a Esquerda? A Vaca Voadora, 28 de novembro. Disponível em: https://avacavoadora.pt/populismo-i-um-programa-analitico/. Acesso em: 16 dez 2020.

FUKUYAMA, F. (2019). Francis Fukuyama: políticos conservadores à la Trump não sabem governar. Disponível em: https://veja.abril.com.br/politica/francis-fukuyama-politicos-conservadores-ala-trump-nao-sabem-governar/. Acesso em: 10 jul 2020.

GASPAR, J.; ANDRÉ, I.; HONÓRIO, F. (2018). “As eleições para a Assembleia da República: 1979-1983. Estudo de Geografia Eleitoral”. In: ESTEVENS, A.; CARMO, A. Isabel André, uma geógrafa inquieta: textos escolhidos. Lisboa, Centro de Estudos Geográficos, Instituto de Geografia e Ordenamento do Território, Universidade de Lisboa.

GASPAR, J.; ANDRÉ, I. (2018). “Portugal - Geografia Eleitoral: 1975-1987”. In: ESTEVENS, A.; CARMO, A. Isabel André, uma geógrafa inquieta: textos escolhidos. Lisboa, Centro de Estudos Geográficos, Instituto de Geografia e Ordenamento do Território, Universidade de Lisboa.

GORDON, I. (2018). In what sense left behind by globalisation? Looking for a less reductionist geography of the populist surge in Europe. Cambridge Journal of Regions, Economy and Society, v. 11, pp. 95-113. DOI: 10.1093/cjres/rsx028.

GUILLUY, C. (2014). La France périphérique - Comment on a sacrifié les classes populaires. Champs actuel. Paris, Flammarion.

JUDIS, J. B. (2016). The Populist Explosion: How the Great Recession Transformed American and European Politics. Nova York, Columbia Global Reports.

KING, G. (1997). "Qualitative Overview". In: KING, G. A solution to the ecological inference problem. Reconstructing individual behavior from aggregate data. Princeton, Princeton University Press.

LISI, M.; LLAMAZARES, I.; TSAKATIKA, M. (2019). Economic crisis and the variety of populist response: evidence from Greece, Portugal and Spain. West European Politics, v. 42, n. 6, pp. 1284-1309. DOI: 10.1080/01402382.2019.1596695. 
LISI, M.; BORGHETTO, E. (2018). Populism, Blame Shifting and the Crisis: Discourse Strategies in Portuguese Political Parties. South European Society and Politics, v. 23, n. 4, pp. 405-427. DOI: 10.1080/13608746.2018.1558606.

MADEIRA, P. M. (2019). Dinâmicas regionais e políticas de desenvolvimento territorial: um olhar cruzado entre a UE e o Brasil. Tese de doutorado. Lisboa, Universidade de Lisboa.

MAGALHÃES, P. (2020). O que pensam os que votaram no Chega? Margens de Erro, 22 de fevereiro. Disponível em: https://www.pedro-magalhaes.org/o-que-pensam-os-que-votaram-no-chega/. Acesso em: 23 dez 2020.

MALHEIROS, J. (2012). "Framing the Iberian model of labour migration. Employment exploitation, de facto deregulation and formal compensation". In: OKOLSKI, M. (ed.). European Immigrations Trends, Structures and Policy Implications. Amesterdã, Amsterdam University Press, pp. 159-178.

MARCHI, R. (2020). A Nova Direita Anti-Sistema. O caso do Chega. Lisboa, Almedina.

MARTIN, R.; TYLER, P.; STORPER, M.; EVENHUIS, E.; GLASMEIER, A. (2018). Globalization at a critical conjuncture? Cambridge Journal of Regions, Economy and Society, v. 11, n. 1, pp. 3-16. DOI:10.1093/cjres/rsy002.

MCCANN, P. (2019). Perceptions of regional inequality and the geography of discontent: insights from the UK. Regional Studies, v. 54, n. 2, pp. 256-267. DOI: 10.1080/00343404.2019.1619928.

MENDES, M.; MAGANO, O.; CANDEIAS, P. (orgs.) (2014). Estudo Nacional sobre as Comunidades Ciganas. Lisboa, Alto Comissariado para as Migrações (ACM, IP).

MOUFFE, C. (2018). For a left populism. Londres/Nova York, Verso.

MUDDE, C. (2004). The Populist Zeitgeist. Government and Opposition, v. 39, n. 4, pp. 541-563. DOI: 10.1111/j.1477-7053.2004.00135.x.

MUDDE, C.; KALTWASSER, C. R. (2017). Populism - A very short introduction. Oxford, Oxford University Press.

RODRÍGUEZ-POSE, A. (2018). The revenge of the places that don't matter (and what to do about it). Cambridge Journal of Regions, Economy and Society, v. 11, n. 1, pp. 189-209. Doi: 10.1093/cjres/ rsx024.

SASSEN, S. (2014). Expulsions - Brutality and Complexity in th Global Economy. Cambridge (MA) e Londres, The Belknap Press.

SGMAI (2019). Históricodaseleições.Disponívelem:https://www.sg.mai.gov.pt/AdministracaoEleitoral/ EleicoesReferendos/HistoricoEleicoes/Paginas/default.aspx?FirtOpen=1. Data de acesso: 3 ago 2020.

TODD, E. (2020). Les Luttes de classes en France au XXIe siécle. Paris, Éditions du Seuil.

Received: August 31, 2020

Approved: December 10, 2020 